\begin{tabular}{|l|l|l|}
\hline \multicolumn{2}{|c|}{ PublisherInfo } \\
\hline \hline PublisherName & $:$ & BioMed Central \\
\hline \hline PublisherLocation & $:$ & London \\
\hline \hline PublisherImprintName & $:$ & BioMed Central \\
\hline \hline
\end{tabular}

\title{
Sanger Institute looks to the future
}

\begin{tabular}{|l|l|l||}
\hline \multicolumn{2}{|c|}{ ArticleInfo } \\
\hline \hline ArticleID & $:$ & 4245 \\
\hline \hline ArticleDOI & $:$ & $10.1186 /$ gb-spotlight-20011106-02 \\
\hline \hline ArticleCitationID & $:$ & spotlight-20011106-02 \\
\hline \hline ArticleSequenceNumber & $:$ & 316 \\
\hline \hline ArticleCategory & $:$ & Research news \\
\hline ArticleFirstPage & $:$ & 1 \\
\hline \hline ArticleLastPage & $:$ & 3 \\
\hline \hline & & RegistrationDate : 2001-11-06 \\
ArticleHistory & $:$ & OnlineDate \\
\hline \hline ArticleCopyright & $:$ & BioMed Central Ltd2001-11-06 \\
\hline \hline ArticleGrants & $:$ & \\
\hline \hline ArticleContext & $:$ & 130592211 \\
\hline \hline
\end{tabular}


The Wellcome Trust Sanger Institute (formerly the Sanger Centre) is moving into the post-genomic era with a new five-year $£ 300$ million plan. Under the leadership of Allan Bradley, the Institute will concentrate on gene function, cancer genomics, and the genomes of model organisms such as the mouse and the zebrafish.

Funded by the Wellcome Trust - the World's largest biomedical charity - the Institute is a leading player in the Human Genome Project Consortium and was responsible for unravelling one third of the human genome. A 'working draft' of the genome was published earlier this year, but the work goes on with the finished sequence expected by 2003. The Sanger Institute will build on the genome investment with new research on gene function and control. In the coming year, one third of the Institute's $£ 63.3$ million funding is earmarked for new projects. "The funding is a very strong commitment to our work by the Trust," said Deputy Director Richard Durbin. "We believe we can continue to play a major role in the post-genomic era, moving from pure DNA studies to protein. A lot of what we're looking at will retain a strong genetic element, however. We also want to see more projects with the other organisations on the Wellcome campus, such as Ensembl - our project with the European Bioinformatics Institute which is the only public domain gene database."

A major focus will be on cancer genomics, with a search for genetic mutations in the most common cancers - breast, lung, colorectal, ovary and prostate. In the first phase of this research, more than 80 genome abnormalities in cancer cells have been identified; this is expected to lead to the discovery of many new cancer genes, including tumor suppressor genes.

Other research will identify genes on the $\mathrm{X}$ chromosome, using techniques employed in the Cancer Genome Project. Initially, this will uncover genes involved in X-linked mental retardation, which is one of the most common genetic disorders. Another project will look into the basis of common multiple gene disorders such as diabetes, asthma and other allergies, by analysis of single nucleotide polymorphisms (SNPs) on the human genome map. Many SNPs are linked to disease susceptibility, so this approach should allow researchers to uncover the genetic basis of these conditions.

In addition, the Institute will continue its work on the genomes of other organisms, focusing on the mouse and the zebrafish. Humans and mice share $85 \%$ of their gene sequences. As part of the International Mouse Genome Sequence Consortium, the Institute is responsible for sequencing $20 \%$ of the mouse genome. The project is due for completion in 2005. The Institute is also committed to the sequencing of the zebrafish genome - another powerful tool for interpreting the human genome. 


\section{References}

1. Wellcome Trust Sanger Institute, [http://www.sanger.ac.uk]

2. Wellcome Trust, [http://www.wellcome.ac.uk]

3. The International Human Genome Sequencing Consortium. Initial sequencing and analysis of the human genome. Nature 2001, 409:860-923., [http://www.nature.com/cgi-taf/DynaPage.taf?file=/nature/ journal/v409/n6822/full/409860a0_fs.html]

4. European Bioinformatics Institute, [http://www.ebi.ac.uk]

5. The Cancer Genome Project, [http://www.sanger.ac.uk/CGP/]

6. Mouse Genome Sequencing Center, [http://www.ncbi.nlm.nih.gov/genome/seq/MmHome.html] 